\title{
Pengembangan Dan Analisis Validitas Modul Pembelajaran Bilingual Berbasis Komputer Pada Pokok Bahasan Perangkat Lunak Pengolah Kata Untuk Siswa Kelas IV Sekolah Dasar
}

\author{
Adlia Alfiriani \\ Program Studi Pendidikan Informatika \\ STKIP PGRI Sumatera Barat \\ alfi69600@yahoo.com
}

\begin{abstract}
ABSTRAK
Penelitian ini berawal dari masalah minimnya media yang berfungsi sebagai sumber belajar yang serta dapat membantu siswa belajar secara individual, khususnya bagi siswa yang melaksanakan proses pembelajaran dengan menggunakan dua bahasa atau bilingual di sekolah berstandar international (SBI). Tujuan dari penelitian ini adalah menghasilkan modul pembelajaran berbasis komputer dengan dua bahasa/atau bilingual yang valid pada pokok bahasan "Perangkat lunak pengolah kata". Jenis penelitian ini adalah penelitian pengembangan dengan menggunakan model Instructional Development Institute (IDI). Penelitian ini dimulai dengan tahap pendahuluan yakni analisis kebutuhan, analisis materi, dan analisis karakteristik siswa. Tahap kedua adalah perencanaan yang terdiri atas rancangan di atas kertas dan rancangan pada komputer. Tahap ketiga adalah evaluasi yakni uji kevalidan oleh pakar dan tindakan berikutnya adalah kegiatan revisi atas saran-saran yang diberikan oleh validator. Hasil uji kevalidan oleh 7 validator menyatakan bahwa prototype dikategorikan sangat valid dengan nilai $\mathrm{Kr}=0,99$ dan $\mathrm{Ks}=0,78$. Koefisisen reproduksibilitas atau $\mathrm{Kr}$ $=0,99$ menunjukkan bahwa ketepatan dari modul pembelajaran bilingual berbasis komputer yang dikembangkan sudah sangat valid karena di atas syarat 0,90 (Masri \& Sofyan, 2006:118). Dengan demikian dapat dikatakan modul pembelajaran bilingual berbasis komputer pada pokok bahasan "Perangkat lunak pengolah kata" ini sudah sangat valid menurut ketujuh validator. Hal ini dipertegas dalam uji skalabilitas dimana koefisien skalabilitas atau $\mathrm{Ks}=0,78$ dimana angka ini sudah memenuhi syarat di atas standar 0,60 (Masri \& Sofyan, 2006:118).
\end{abstract}

Kata Kunci: Modul Pembelajaran Bilingual,Berbasis Komputer, Perangkat Lunak Pengolah Kata

\section{PENDAHULUAN}

Pada dasawarsa terakhir ini terjadi perkembangan yang begitu pesat dan mengagumkan dari pertumbuhan teknologi informasi dan komunikasi yang ditandai dengan lahirnya berbagai produk elektronik canggih, yang mungkin belum pernah terbayangkan sebelumnya. Seiring dengan perkembangan teknologi informasi dan komunikasi tersebut pemerintah selalu berupaya untuk meningkatkan kualitas sumber daya manusia. Salah satu langkah yang dilakukan pemerintah adalah mengevaluasi kurikulum yang ditetapkan pada setiap jenjang pendidikan. Upaya ini terlihat pada tahun 2004 pemerintah berhasil merealisasikan kurikulum yang berorientasi pada kompetensi yang harus dimiliki oleh peserta didik yang dikenal dengan istilah Kurikulum Berbasis Kompetensi (KBK). Banyak pembaharuan yang terjadi akibat diterapkannya kurikulum ini, salah satunya adalah ditetapkannya mata pelajaran Teknologi Informasi dan komunikasi (TIK) sebagai mata pelajaran wajib yang harus dipelajari oleh siswa pada semua jenjang pendidikan sebagai wujud untuk memenuhi tuntutan global.

Dengan berbagai keterbatasan, pada awalnya mata pelajaran TIK ini hanya ditetapkan untuk dilaksanakan pada tingkat SLTP dan SLTA saja. Kemudian seiring berjalannya waktu dan dengan upaya yang sungguh-sungguh dari pemerintah, pada beberapa tahun terakhir mata pelajaran TIK sudah dapat dilaksanakan di tingkat sekolah dasar walaupun masih belum optimal. Usaha 
pemerintah tidak berhenti sampai di sini, pada tahun 2006 pemerintah berhasil menyempurnakan KBK menjadi Kurikulum Tingkat Satuan Pendidikan (KTSP). Penyempurnaan kurikulum ini dilakukan guna memenuhi tuntutan perkembangan informasi, ilmu pengetahuan, teknologi, seni dan tuntutan desentralisasi dan hak manusia.

Upaya lain yang dilakukan pemerintah dalam meningkatkan mutu pembelajaran dan pendidikan di Indonesia adalah dengan mengeluarkan Undang-undang no. 20 tahun 2003 Pasal 50 ayat 3 yang menyatakan "Pemerintah Pusat atau Pemerintah Daerah menyelenggarakan sekurang-kurangnya satu satuan pendidikan pada semua jenjang pendidikan untuk dikembangkan menjadi satuan pendidikan yang bertaraf Internasional" dan hal ini diperkuat oleh Permendiknas no. 78 tahun 2009, tentang penyelenggaraan sekolah bertaraf internasional pada jenjang pendidikan dasar dan menengah. Walaupun hal ini masih sulit untuk dilaksanakan mengingat belum siapnya semua komponen pendidikan pada setiap kabupaten/kota dan minimnya infrastruktur yang ada, tetapi pemerintah pusat dan pemerintah daerah terus berupaya untuk mewujudkannya.

Menjadi salah satu kewajiban bagi Sekolah Berstandar Internasional (SBI) atau Rintisan Sekolah Berstandar Internasional (RSBI) untuk melaksanakan proses pembelajaran dengan menggunakan dua bahasa atau bilingual yakni bahasa Indonesia dan bahasa Inggris pada setiap mata pelajaran, tidak terkecuali pada mata pelajaran Teknologi Informasi dan Komunikasi (TIK). Penggunaan bilingual atau dua bahasa ini menuntut pihak sekolah untuk menyiapkan tenaga pendidik yang fasih dalam dua bahasa atau paling tidak menghadirkan dua orang guru (guru bidang studi dan translator) dalam satu kelas serta menyiapkan banyak sumber belajar dan media pembelajaran dalam dua bahasa juga. Menghadirkan dua orang guru sekaligus di dalam kelas hanya dapat memenuhi kebutuhan belajar siswa secara klasikal, tetapi belum bisa memenuhi kebutuhan belajar siswa secara individual. Maka dari itu dibutuhkan suatu media pembelajaran yang berfungsi sebagai sumber belajar yang juga diprogram dengan menggunakan dua bahasa atau bilingual sehingga dapat memenuhi kebutuhan tersebut.

Guru maupun sekolah menghadapi kendala dalam melaksanakan proses pembelajaran TIK di Sekolah Berstandar Internasional (SBI) atau Rintisan Sekolah Berstandar Internasional (RSBI), karena mata pelajaran TIK ini memerlukan waktu yang cukup banyak bagi siswa untuk melakukan pengulangan pembelajaran karena sifat materinya yang aplikatif, sementara waktu yang disediakan pihak sekolah relatif sedikit, hanya 2 jam pelajaran pada setiap minggunya. Hal ini menjadi alasan penting untuk memberikan peluang-peluang serta memfasilitasi siswa untuk belajar secara individual di luar jam pelajaran yang disediakan oleh sekolah agar tujuan dari pembelajaran itu sendiri dapat tercapai secara optimal.

Berdasarkan survey awal yang penulis lakukan di SD Negeri Percobaan Padang (kebetulan SD Negeri percobaan padang sampai saat ini masih tercatat sebagai salah satu sekolah dasar yang sudah berstandar internasional) yang melaksanakan proses pembelajaran dengan menggunakan dua bahasa yakni bahasa Indonesia dan bahasa Inggris, peneliti melihat bahwa guru masih mengalami kesulitan dalam melaksanakan proses pembelajaran khususnya pada kompetensi dasar atau pokok bahasan "Perangkat lunak pengolah kata". Disamping itu, peneliti juga melihat bahwa tidak semua siswa mampu mengikuti proses pembelajaran dengan bahasa pengantar bahasa Inggris terlebih pada siswa kelas IV sekolah dasar yang sebelumnya sudah terbiasa dengan pembelajaran dua bahasa, ini dikarenakan oleh minimnya kemampuan mereka meraka dalam memahami dan mengkomunikasikan bahasa tersebut. Kesulitan lain yang dihadapi diantaranya adalah kurangnya media pembelajaran maupun sumber belajar yang dapat membantu siswa belajar secara individual dan dibuat dalam dua bahasa atau bilingual sehingga guru hanya mengandalkan komunikasi lisan yang mereka lakukan di dalam kelas, buku paket yang disediakan oleh penerbit tidak banyak yang diprogram dalam dua bahasa atau bilingual (di Kota Padang buku paket TIK Sekolah Dasar Bilingual hanya dari penerbit Yrama Widya), seringnya ketidakhadiran transletor di dalam 


\section{Jurnal Edik Informatika \\ Penelitian Bidang Komputer Sains dan Pendidikan Informatika \\ V2.i1(1-9)}

ISSN : 2407-0491

kelas (guru yang membimbing siswa dalam komunikasi bahasa Inggris). Salah satu usaha yang dapat dilaksanakan guru sebagai fasilitator pembelajaran adalah memberikan kesempatan untuk anak belajar secara individual di dalam maupun di luar jam pelajaran sekolah.

Untuk mewujudkan hal ini, diperlukan suatu media yang dapat menyampaikan materi pelajaran kepada siswa dan dapat membantu mereka untuk mengkonstruksikan pengetahuan/pemahamannya sendiri. Media ini dapat dibuat oleh guru itu sendiri atau dengan meminta bantuan kepada pihak ketiga di luar sistem pembelajaran. Media yang dapat memenuhi kebutuhan belajar siswa secara individual adalah modul. Dengan adanya modul ini siswa dapat melakukan pengulangan pembelajaran di luar jam sekolah, dan agar modul ini dapat memenuhi kebutuhan sekolah berstandar internasional (SBI) yang notabene menggunakan dua bahasa dalam proses pembelajaran maka modul pembelajaran untuk siswa SBI juga perlu menggunakan dua bahasa yakni bahasa Indonesia dan bahasa Inggris, dalam menyajikan informasi secara visual maupun secara audio.

Pada awalnya modul dibuat dalam bentuk buku teks yang sifatnya verbal. Namun seiring dengan perkembangan Teknologi modul dapat dibuat dengan proses komputerisasi. Dengan menggabungkan beberapa perangkat lunak yang terdapat pada komputer seperti perangkat lunak pengolah kata, pengolah persentase, dan pengolah suara, guru/desainer dapat merancang suatu modul pembelajaran yang berbasis komputer. Sistem komputerisasi ini juga memungkinkan untuk memberikan warna, gambar, dan penggunaan huruf yang ukurannya disesuaikan dengan karakteristik dari siswa sekolah dasar.

Berdasarkan uraian di atas, penulis mengembangkan sebuah modul yang disesuaikan dengan karakteristik dan kebutuhan siswa serta dengan perkembangan teknologi yang ada. Untuk mendukung ini, maka modul ini disajikan dalam dua bahasa yakni bahasa Indonesia dan bahasa Inggris, baik secara tulis maupun lisan serta dirancang dengan menggunakan hardware dan software komputer. penulis juga melakukan analisis validasi terhadap modul ini agar memiliki tingkat kesahihan sehingga sesuai dan relevan terhadap IPTEKS.

\section{METODE}

\section{a. Model Pengembangan}

Jenis penelitian yang akan dilakukan adalah penelitian dan pengembangan (Research and development /R\&D). $\mathrm{R} \& \mathrm{D}$ adalah metode penelitian yang digunakan untuk menghasilkan produk tertentu dan menguji keefektifan produk tersebut. yaitu pengembangann modul pembelajaran bilingual berbasis komputer pada pokok bahasan "Perangkat lunak pengolah kata" untuk siswa kelas IV sekolah dasar.

\section{b. Prosedur Pengembangan}

\section{- Analisis Kebutuhan}

Analisis kebutuhan merupakan langkah awal dalam penelitian pengembangan. Pada tahap ini peneliti melakukan wawancara dengan guru TIK dan siswa untuk mengetahui hambatan apa saja yang dihadapi dalam kegiatan pembelajaran TIK kelas IV sekolah dasar. Selanjutnya peneliti menganalisis materi pokok yakni pokok bahasan "Perangkat lunak pengolah kata" untuk dikembangkan dalam perancangan bahan ajar sesuai dengan kompetensi dasar. Peneliti juga menganalisis karakteristik siswa, yang terdiri dari gaya belajar dan kemampuan awal mereka, menganalisis sumber-sumber belajar serta menganalisis kemampuan guru dalam menggunakan media dalam kegiatan pembelajaran TIK di sekolah dasar. Semuanya ini dilakukan agar dapat membantu peneliti dalam mengembangkan bahan ajar yang akan digunakan dalam pembelajaran Teknologi Informasi dan Komunikasi.

\section{- Desain/ Perancangan}

Modul pembelajaran bilingual yang dikembangkan ini dibuat dengan menggunakan perangkat keras komputer dan berbagai perangkat lunak seperti Microsoft Powerpoint, Arct Soft dan Cool Edit Pro sehingga modul pembelajaran yang dikembangkan ini bersifat interaktif, menarik dan audiovisual. Kemudian modul disimpan ke dalam CD agar bisa diberikan kepada masing-masing siswa.

Proses perancangan prototipe dimulai dari paper-based dan pada tahap selanjutnya 
dengan computer-based. Adapun siklus prototipe adalah sebagai berikut : (1) Rancangan modul pembelajaran bilingual berbasis komputer (prototipe) dievaluasi oleh beberapa pakar/ahli dengan mengisi lembar validasi dan selanjutnya prototipe direvisi sesuai dengan saran-saran yang diberikan oleh pakar. Jaali (2004: 34) mengemukakan: "suatu media memiliki validitas isi yang baik jika mampu mengukur penguasaan materi yang seharusnya dikuasai sesuai dengan konten pembelajaran yang tercantum dalam kurikulum. Sedangkan suatu media memiliki validitas konstruk yang baik jika mampu mengukur apa yang benar-benar diukur sesuai dengan konsep yang telah ditetapkan".

\section{- Evaluasi/Revisi}

Pada tahap ini produk yang telah dibuat dievaluasi melalui uji kevalidan modul Pembelajaran Bilingual Berbasis Komputer. Uji kevalidan dilakukan dengan memperlihatkan modul pembelajaran bilingual berbasis komputer kepada para pakar yang terdiri dari tujuh orang Dosen/ tenaga pengajar pada perguruan tinggi yang dipilih berdasarkan keahlian yang dimilikinya. Pemilihan ahli atau pakar guna kepentingan kegiatan uji kevalidan modul pembelajaran bilingual berbasis komputer yang dikembangkan dalam penelitian ini didasarkan pada bidang keahliannya dan rekomendasi dari dosen pembimbing.

Tahap validasi modul pembelajaran bilingual berbasis komputer dilakukan para pakar dengan mengisi lembar validasi yang telah disiapkan sebelumnya, kemudian berdasarkan saran-saran yang diberikan, peneliti merivisi desain modul pembelajaran bilingual berbasis komputer sampai dinyatakan bahwa desain yang dihasilkan valid.

\section{HASIL DAN PEMBAHASAN}

\section{A. Hasil Penelitian}

\section{1) Analisis Pendahuluan}

Prototipe modul pembelajaran bilingual berbasis komputer pada pokok bahasan "Perangkat lunak pengolah kata" dirancang berdasarkan analisis kebutuhan (Need Assesment). Kegiatan ini dimulai dari analisis kebutuhan lapangan, analisis materi dan analisis karakteristik siswa.

\section{- Analisis kebutuhan}

Tuntutan Permendiknas Nomor 78 pasal 22 Tahun 2009, adalah setiap Pemerintah Kabupaten/Kota wajib menyelenggarakan paling sedikit 1 (satu) sekolah dasar bertaraf internasional. Adapun tujuan diselenggarakannya sekolah bertaraf internasional agar lulusannya memiliki : (1) kompetensi yang sesuai dengan stantar kompetensi pada salah satu sekolah terakreditasi di negara maju; (2) daya saing komparatif tinggi; (3) kemampuan bersaing dalam berbagai lomba di tingkat internasional; (4) kemampuan bersaing kerja di luar negeri; (5) kemampuan berkomunikasi dalam bahasa Inggris; (6) kemampuan berperan aktif secara internasional dalam menjaga kelangsungan hidup dan perkembangan dunia di berbagai bidang; dan (7) kemampuan menggunakan dan mengembangkan teknologi informasi dan komunikasi secara profesional (Permendiknas No 78 Bab 1 Pasal 2 tahun 2009).

Untuk mencapai tujuan di atas, ada beberapa kriteria yang menjadi standar dalam pelaksanaan proses pembelajaran. Adapun kriteria pelaksanaan proses pembelajaran menurut Permendiknas No 78 Pasal 22 Tahun 2009 diantaranya adalah (1) Proses pembelajaran dilaksanakan dengan menerapkan pendekatan pembelajaran berbasis teknologi infomasi dan komunikasi, aktif, kreatif, efektif, menyenangkan dan kontekstual (2) menggunakan bahasa pengantar bahasa Inggris dalam proses pembelajaran minimal bilingual.

$$
\text { Untuk melaksanakan proses }
$$
pembelajaran TIK yang sesuai dengan ketentuan di atas guru dan sekolah dituntut untuk menyediakan berbagai sumber belajar atau media berbasis digital yang berbahasa Inggris. Pada kenyataannya sekolah-sekolah yang sudah berstandar internasional khususnya untuk tingkat sekolah dasar belum mampu mengembangkan sumber belajar atau media yang dapat membantu siswa untuk mencapai kompetensi yang harus dimilikinya setelah mengikuti mata pelajaran TIK . Guru hanya menggunakan sumber belajar yang sudah ada yaitu 1 buku cetak mata pelajaran TIK yang bilingual terbitan Yrama Widia dan buku cetak lain yang berbahasa Indonesia terbitan Erlangga. Kondisi ini menyulitkan siswa dalam membangun pengalaman belajarnya. 
Berdasarkan hasil dari analisis kebutuhan di atas dapat dikatakan bahwa sekolah dasar berstandar internasional sangat memerlukan media pembelajaran yang berfungsi sebagai sumber belajar dalam menerapkan pembelajaran bilingual yang berbasis teknologi informasi dan komunikasi . Dari analisis kebutuhan inilah peneliti berkeinginan untuk mengembangkan sebuah modul pembelajaran bilingual yang berbasis komputer untuk mata pelajaran TIK.

\section{a. Analisis materi}

Komponen kurikulum yang terkait langsung dengan produk yang dihasilkan adalah Standar Kompetensi (SK) dan Kompetensi Dasar (KD). SK dan KD mata pelajaran TIK di sekolah dasar merupakan standar minimum yang secara nasional dan internasional harus dicapai oleh peserta didik. Pencapaian SK dan KD ditujukan guna pemberdayaan peserta didik untuk membangun kemampuan, bekerja ilmiah, dan membangun pengetahuannya sendiri yang difasilitasi oleh guru dan sekolah. Analisis ini dilakukan dengan menganalisis standar isi untuk SD/MA pada kurikulum 2004 untuk mata pelajaran Teknologi Informasi dan Komunikasi.

Berdasarkan Standar isi pada kurikulum 2004, bahan kajian mata pelajaran Teknologi Informasi dan Komunikasi untuk siswa kelas 1 sampai dengan 6 sekolah dasar, sebahagian besar difokuskan pada kegiatan yang bersifat apresiatif dan aplikatif, sedikit tentang kegiatan produktif dan evaluatif

Sedangkan materi atau pokok bahasan pada mata pelajaran TIK yang dipelajari siswa kelas 1 s/d 6 sekolah dasar adalah : (1) Pengenalan perangkat keras komputer, (2) Pengenalan perangkat lunak pengolah gambar, (3) Penggunaan ikon-ikon pada perangkat lunak pengolah gambar, (4) Pengenalan perangkat lunak pengolah kata, (5) Pengenalan perangkat lunak pengolah persentase, (6) Penggunaan perangkat lunak pengolah prersentasi.

"Menunjukan, mendemonstrasikan dan mengolah dokumen dengan program Ms. Word" merupakan standar kompetensi yang harus dicapai oleh siswa yang duduk di kelas IV sekolah dasar. Ada beberapa kompetensi dasar yang harus dimiliki siswa untuk mendukung tercapainya standar kompetensi tersebut, yaitu :
(1) mengenal software pengolah kata, (2) menggunakan fitur-fitur umum dari software pengolah kata untuk mengedit dan memformat teks, dan (3) mengolah dokumen.

Pada kompetensi dasar "Mengenal perangkat lunak pengolah kata" materi pokok yang harus dikuasai oleh siswa adalah ikon perangkat lunak pengolah kata. Adapun submateri dari ikon perangkat lunak pengolah kata adalah : (1) membuka program perangkat lunak pengolah kata, (2) mengenal lembar kerja Microsoft Word, (3) mengenal menu-menu yang terdapat pada Microsoft Word, (4) menunjukkan fungsi dari ikon-ikon yang terdapat pada program Microsoft Word, dan (5) mengidentifikasi menu-menu yang terdapat pada program Mcrosoft Word.

Berdasarkan hasil analisis materi di atas, ada beberapa hal penting yang menjadi perhatian, yaitu : (1) bahan kajian mata pelajaran TIK di SD bersifat apresiatif dan aplikatif, dan pengetahuan dasar; (2) standar kompetensi yang harus dimiliki siswa kelas IV sekolah dasar setelah mengikuti mata pelajaran TIK adalah "menunjukan, mendemonstrasikan dan mengolah dokumen dengan program $M s$. Word"; (3) ada 3 kompetensi dasar yang harus dimiliki siswa untuk mendukung tercapainya standar kompetensi, salah satunya "Mengenal perangkat lunak pengolah kata"; (4) sedangkan materi pokok yang harus dipelajari siswa untuk mencapai kompetensi dasar tersebut adalah menjalakan program perangkat lunak pengolah kata, mengenal lembar kerja, mengenal menumenu, mengenal ikon yang terdapat pada lembar kerja word.

\section{b. Analisis karakteristik siswa}

Analisis karakteristik siswa dilakukan
untuk membantu peneliti dalam mengembangkan modul pembelajaran bilingual berbasis komputer. Hasil analisis ini dijadikan pertimbangan bagi peneliti dalam mendesain produk. Subjek ujicoba dari penggunaan modul pembelajaran bilingual berbasis komputer yang dikembangkan ini adalah siswa kelas IVb sekolah dasar Negeri Perocobaan Padang yang berjumlah 24 orang siswa. Pada umumnya, mereka memiliki motivasi yang tinggi dalam melaksanakan proses pembelajaran, memiliki kemampuan belajar dengan menggunakan 


\section{Jurnal Edik Informatika \\ Penelitian Bidang Komputer Sains dan Pendidikan Informatika \\ V2.i1(1-9)}

ISSN : 2407-0491

perangkat teknologi informasi dan komunikasi yang cukup tinggi sehingga guru dan sekolah dituntut untuk mampu memfasilitasi siswa belajar dengan berbasis komputer, baik secara klasikal maupun individual. Siswa kelas IVb sekolah dasar ini sangat menyenangi mata pelajaran TIK, ini dapat dibuktikan dengan aktivitas dan hasil belajar mereka yang sangat baik pada pokok bahasa sebelumnya. Walaupun siswa ini sudah diwajibkan untuk menggunakan bahasa Inggris sebagai bahasa pengantar dalam proses pembelajaran, tetapi ada sebahagian dari mereka yang berlum terlalu fasih dalam berbahasa Inggris. Hal ini menyulitkan mereka dalam memahami materi pelajaran. Atas dasar itulah peneliti mengembangkan media pembelajaran yang sekaligus dapat dijadikan sumber belajar berupa modul pembelajaran yang dapat membantu siswa kelas IV sekolah dasar dalam melaksanakan proses pembelajaran TIK.

1. Tahap Perancangan/ Desain Modul Pembelajaran

a. Tahap Pendesainan pada Kertas

Tahap ini berisi desain yang dimulai dari sketsa gambar pada kertas, dengan tujuan untuk memperoleh gambaran tentang bentuk apa saja yang akan ditampilkan pada computerbased. Desain ini terdiri dari cover, pengantar, $\mathrm{SK}, \mathrm{KD}$, daftar isi yang link dengan kegiatan belajar 1, kegiatan belajar 2, kegiatan belajar 3 , kegiatan belajar 4, dan daftar pustaka. Kegiatan belajar dibagi dalam beberapa bagian, yaitu : materi pelajaran, rangkuman, tes, kunci jawaban dan umpan balik. Paper-based dari modul pembelajaran bilingual dapat dilihat pada Lampiran 10.

b.

pada komputer

Tahap Pendesainan

Setelah modul didesain di atas kertas selanjutnya dipindahkan ke komputer. Pendesainan pada komputer menggunakan perangkat lunak pengolah persentasi atau Mcrosoft Powerpoint 2007 untuk membuat template modul dan software cool edit pro digunakan untuk merekam dan mengedit suara. Sound atau teks lisan pada prototipe pertama dirancang hanya menggunakan satu pengisi suara (suara perempuan saja), pengisi suara ini berfungsi ganda, yakni melafaskan teks lisan dalam bahasa Indonesia dan teks lisan dalam bahasa Inggris.

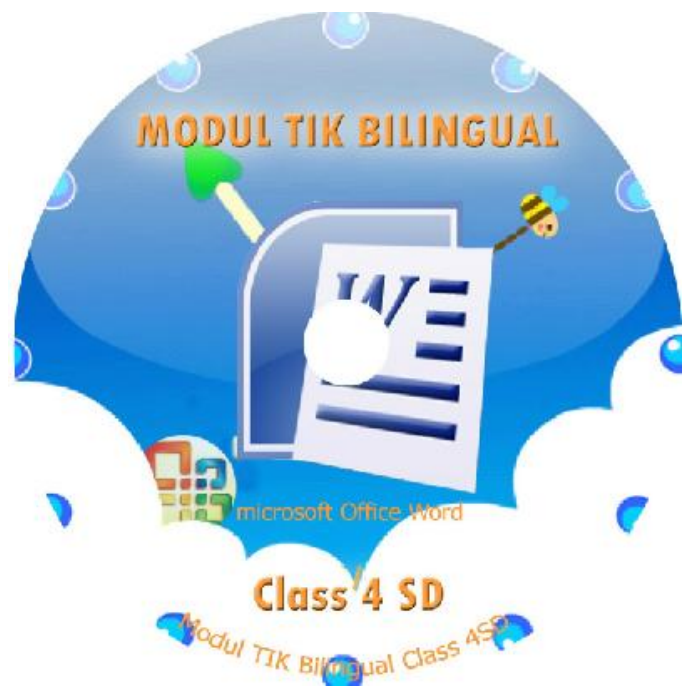

Gambar 1. Cover CD Modul

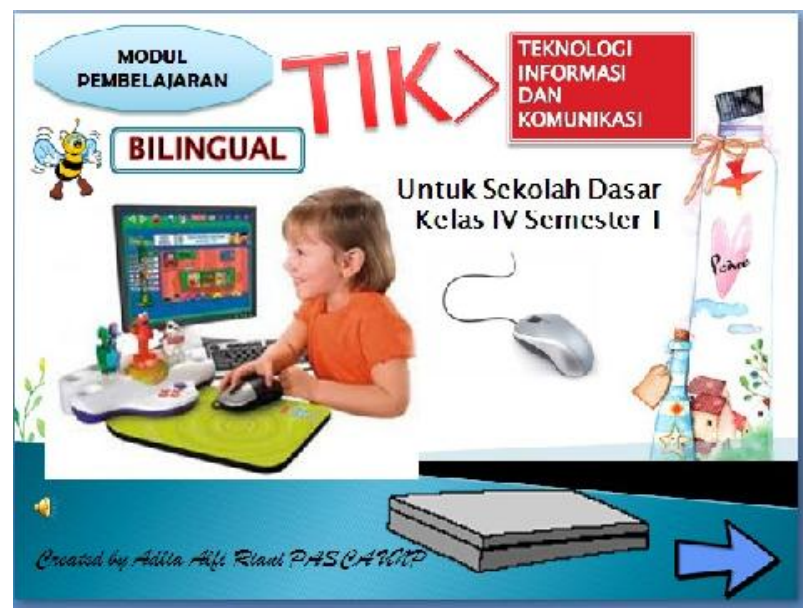

Gambar 2. Tampilan Awal Modul 


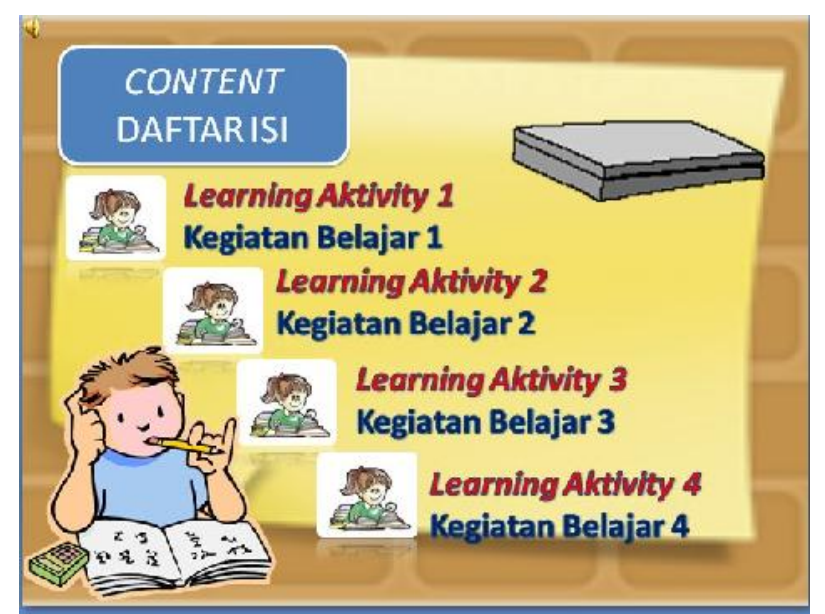

Gambar 3. Tampilan Daftar Isi Modul

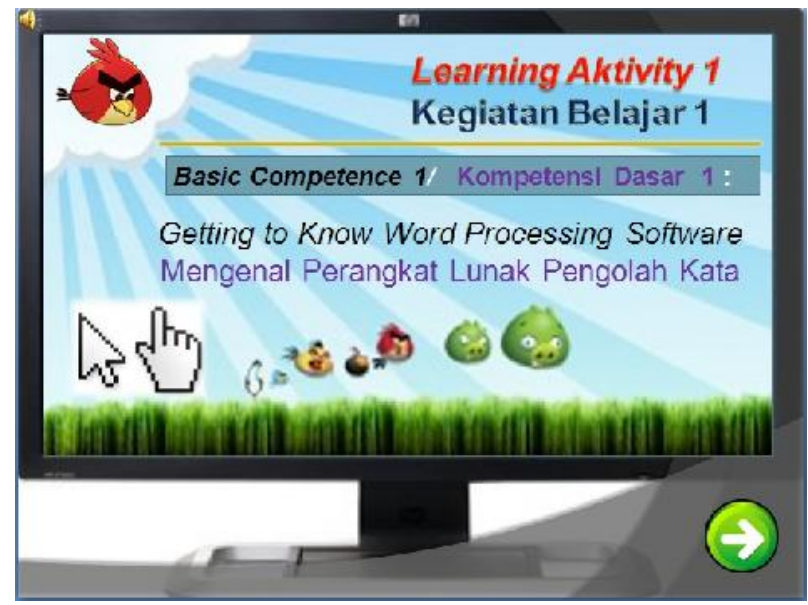

Gambar 4. Tampilan untuk SK dan KD

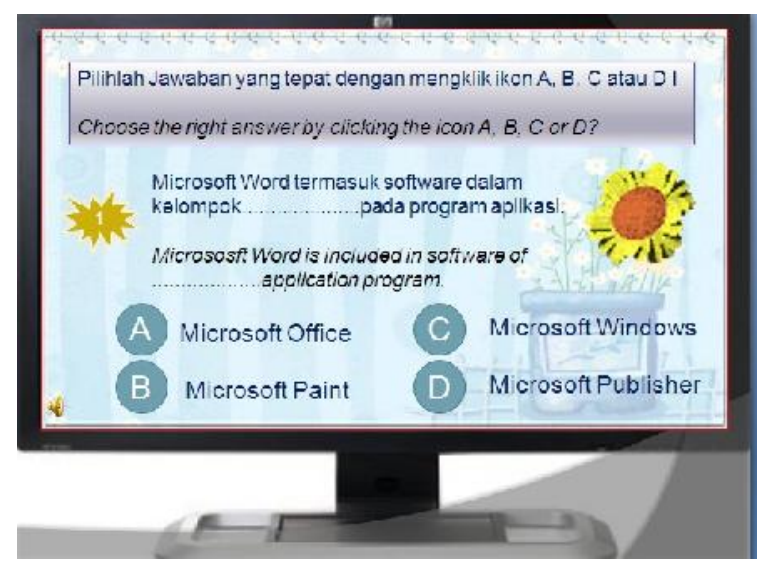

Gambar 5. Tampilan untuk latihan

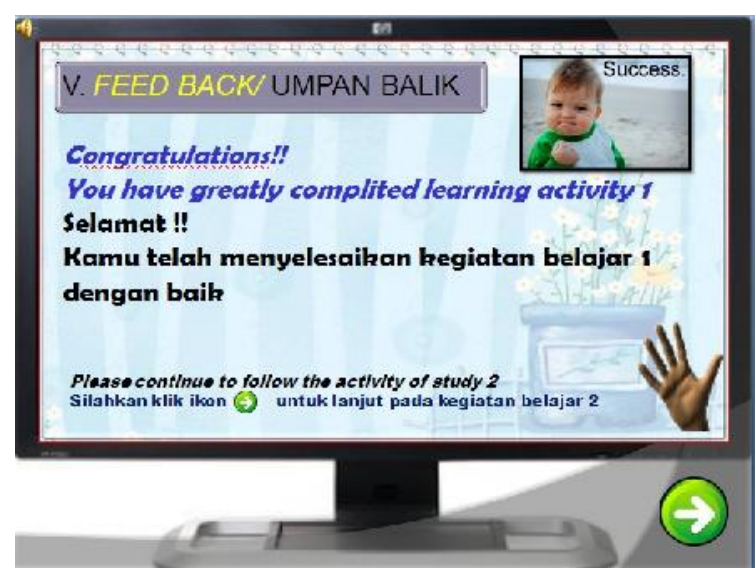

Gambar 6. Tampilan untuk umpan balik

\section{c. Evaluasi dan Revisi}

Evaluasi dilakukan melalui uji kevalidan ptototipe pertama modul oleh pakar, Adapun hasil analisis dari kegiatan evaluasi tersebut adalah :

Modul yang sudah didesain pada komputer divalidasi oleh tujuh validator dengan menggunakan lembar uji validitas Berdasarkan hasil penilaian yang diberikan validator melalui lembaran validasi, semua jawaban validator didistribusikan ke dalam tabel Guttman. Secara kongkrit jawaban tersebut dapat dilihat pada Tabel 1 .

\section{Tabel 1. Hasil Validasi Modul Pembelajaran Bilingual Berbasis Komputer}

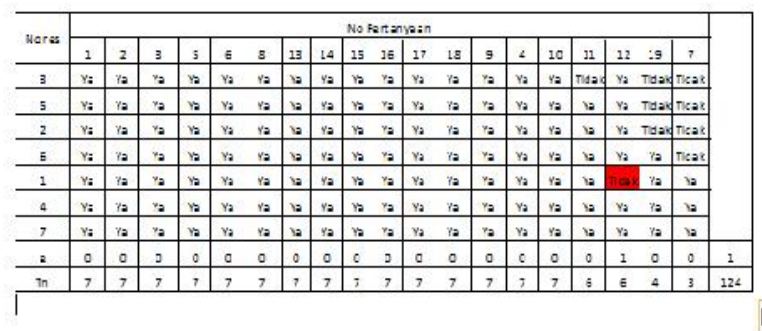

Setelah semua jawaban yang diberikan validator tersusun ke dalam tabel Guttman, maka langkah selanjutnya dihitung nilai skala ekonomis dengan menggunakan analisis skalogram. Untuk ini perlu dihitung jumlah kesalahan (e). Kalau dihitung sel-sel yang kosong dari jawaban "Ya" yang menyeleweng pada kolom pertanyaan 1 sampai 19 dalam Tabel 3, jumlah kesalahan adalah 1. Setelah didapat kesalahan jawaban, maka langkah 


\section{Jurnal Edik Informatika \\ Penelitian Bidang Komputer Sains dan Pendidikan Informatika \\ V2.i1(1-9)}

ISSN : 2407-0491

selanjutnya adalah menghitung koefisien reproduksibilitas $(\mathrm{Kr})$ yang menunjukkan tingkat kevalidan prototipe dengan menggunakan rumus berikut :

$$
\begin{gathered}
\mathrm{Kr} \\
=
\end{gathered} \quad 1-\frac{\text { Jumlah kesalahan }}{\begin{array}{c}
\text { Jumlah pertanyaan X jumlah } \\
\text { responden }
\end{array}}
$$

\section{Atau}

$\mathrm{Kr}=1-\mathrm{e} / \mathrm{n}$

Dimana :

$\mathrm{Kr} \quad=$ Koefisien reproduksibilitas

$\mathrm{E} \quad=$ Jumlah kesalahan $=1$

$\mathrm{N}=$ Jumlah pertanyaan $\mathrm{x}$ jumlah responden $=19 \times 7=133$

$$
\begin{aligned}
\mathrm{Kr} & =1-\mathrm{e} / \mathrm{n} \\
& =1-1 / 133 \\
& =1-0,0075188 \\
& =0,99
\end{aligned}
$$

Setelah $\mathrm{Kr}$ diketahui, dihitung koefisien skalabilitas dengan menggunakan rumus :

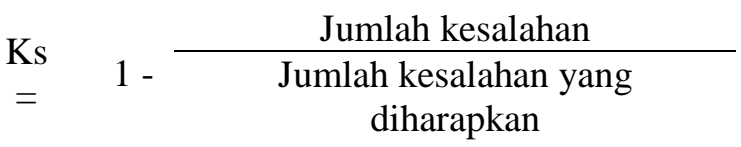

Atau

$\mathrm{Ks}=1-\mathrm{e} / \mathrm{k}$

Dimana,

Ks = Koefisien skalabilitas

$\mathrm{E} \quad=$ Jumlah kesalahan $\quad=1$

$\mathrm{K}$ = Jumlah kesalahan yang diharapkan atau c (n-Tn) dan c adalah kemungkinan mendapatkan jawaban yang benar. Karena jawabannya adalah "Ya" dan "Tidak" c $=0,5$

$\mathrm{N}=$ Jumlah jawaban $=133$

$\mathrm{Tn}=$ Jumlah pilihan jawaban $=124$

Maka,

$$
\begin{aligned}
\mathrm{Ks} & =1-\mathrm{e} / \mathrm{k} \\
& =1-1 / 0,5(133-124) \\
& =1-1 / 0,5(9) \\
& =1-1 / 4,5 \\
& =1-0.22 \\
& =0,78
\end{aligned}
$$

Koefisisen reproduksibilitas atau $\mathrm{Kr}=$ 0,99 menunjukkan bahwa ketepatan dari modul pembelajaran bilingual berbasis komputer yang dikembangkan sudah sangat valid karena di atas syarat 0,90 (Masri \& Sofyan, 2006:118). Dengan demikian dapat dikatakan modul pembelajaran bilingual berbasis komputer pada pokok bahasan "Perangkat lunak pengolah kata" ini sudah sangat valid menurut ketujuh validator. Hal ini dipertegas dalam uji skalabilitas dimana koefisien skalabilitas atau $\mathrm{Ks}=0,78$ dimana angka ini sudah memenuhi syarat di atas standar 0,60 (Masri \& Sofyan, 2006:118).

Setelah diperoleh derajat kesahihan dari modul pembelajaran bilingual berbasis komputer ini, langkah selanjutnya adalah melakukan revisi sesuai dengan saran-saran yang diberikan validator melalui lembaran validasi. Adapun saran-saran yang diberikan validator dijabarkan dalam Tabel 2, sebagai berikut :

Tabel 2. Saran-saran Validator

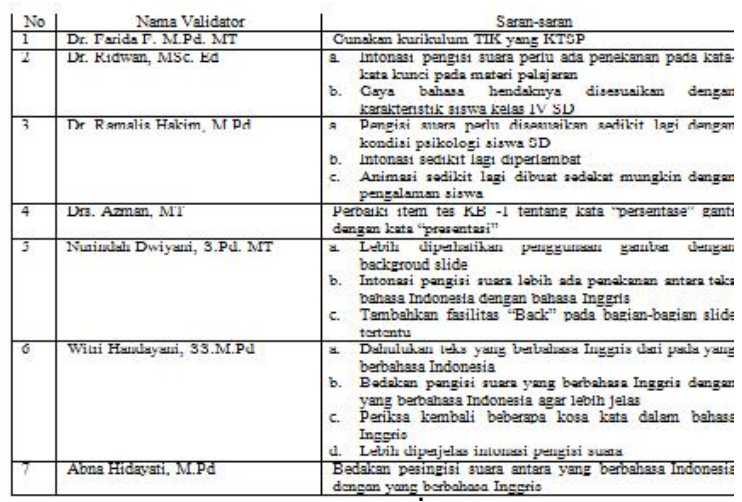

Berdasarkan saran-saran yang diberikan validator yang diuraikan dalam Tabel 2, prototipe pertama direvisi sehingga hasil revisi tersebut menjadi layak untuk diujicobakan sebagai media pembelajaran pada mata pelajaran TIK siswa kelas IV sekolah dasar. Adapun hasil revisi porototipe dapat dilihat pada Tabel 3. 
Tabel 3. Perubahan Prototipe Pertama Menjadi Prototipe Kedua

\begin{tabular}{|c|c|c|c|}
\hline No & $\begin{array}{l}\text { Prototipe } \\
\text { Pertama }\end{array}$ & & Prototipe Kedua \\
\hline 1 & $\begin{array}{lr}\text { Pengisi } & \text { suara } \\
\text { untuk } & \text { bahasa } \\
\text { Inggris } & \text { sama } \\
\text { dengan } & \text { pengisi } \\
\text { suara bahasa } \\
\text { Indonesia } \quad(1 \\
\text { orang) }\end{array}$ & a) & $\begin{array}{l}\text { Pengisi suara laki- } \\
\text { laki untuk bahasa } \\
\text { Inggris dan pengisi } \\
\text { suara perempuan } \\
\text { untuk bahasa } \\
\text { Indonesia }\end{array}$ \\
\hline 2 & $\begin{array}{l}\text { Soundnya tidak } \\
\text { ada intonasi } \\
\text { dan kurang } \\
\text { dekat dengan } \\
\text { karakteristik } \\
\text { siswa }\end{array}$ & b) & \begin{tabular}{lr}
\multicolumn{1}{c}{ Ada penekanan } \\
suara untuk kata- \\
kata tertentu, dan \\
suaranya lebih ceria \\
sehingga lebih \\
dekat dengan \\
karakteristik siswa
\end{tabular} \\
\hline 3 & $\begin{array}{l}\text { Teks bahasa } \\
\text { Indonesia } \\
\text { terlebih dahulu, } \\
\text { baru diikuti } \\
\text { dengan teks } \\
\text { berbahasa } \\
\text { Inggris }\end{array}$ & c) & \begin{tabular}{lr}
\multicolumn{1}{c}{ Teks } & berbahasa \\
Inggris & terlebih \\
dahulu, baru diikuti \\
dengan \\
berbahasa Indonesia
\end{tabular} \\
\hline 4 & $\begin{array}{l}\text { Banyak } \\
\text { terdapat gambar } \\
\text { diam maupun } \\
\text { gambar } \\
\text { bergerak dalam } \\
\text { setiap slide }\end{array}$ & d) & $\begin{array}{lr}\text { Gambar } & \text { diam } \\
\text { dan } & \text { gambar } \\
\text { bergerak } & \text { dikurangi, } \\
\text { hanya } & \text { pada } \\
\text { beberapa slide saja }\end{array}$ \\
\hline 5 & $\begin{array}{l}\text { Kata } \\
\text { "presentase" } \\
\text { pada tes KB } 1\end{array}$ & e) & $\begin{array}{lr}\text { Kata } & \\
\text { "persentase" } & \text { diganti } \\
\text { dengan } & \text { kata } \\
\text { "presentasi" }\end{array}$ \\
\hline 6 & $\begin{array}{l}\text { Tombol "Back" } \\
\text { hanya pada tes } \\
\text { saja }\end{array}$ & f) & $\begin{array}{l}\text { Menambahkan } \\
\text { tombol "Back" pada } \\
\text { beberapa slide } \\
\text { materi pelajaran }\end{array}$ \\
\hline
\end{tabular}

\section{KESIMPULAN}

Penelitian pengembangan ini berawal dari minimnya media pembelajaran yang sekaligus berfungsi sebagai sumber belajar pada sekolah berstandar internasional (SBI) khususnya pada tingkat sekolah dasar. Oleh karena itu dikembangkanlah sebuah modul pembelajaran bilingual berbasis komputer dengan tujuan untuk memenuhi kebutuhan siswa dalam memperoleh pengetahuan secara optimal. Modul pembelajaran bilingual berbasis komputer dikembangkan melalui penelitian $\mathrm{R}$ \& D dengan 4 tahapan, yakni : (a) tahap analisis kebutuhan, analisis materi dan analisis karakteristik siswa; (b) tahap perancangan di atas kertas dan perancangan pada komputer; (c) tahap evaluasi dengan melakukan uji kevalidan, uji kepraktisan dan uji keefektivan; dan (d) tahap revisi. Melalui uji kevalidan yang dilakukan oleh 7 orang validator , modul pembelajaran bilingual berbasis komputer yang dikembangkan dinyatakan memiliki tingkat kevalidan yang tinggi sehingga layak untuk di gunakan.

\section{DAFTAR PUSTAKA}

Akker and Ploom. 1999. Design Approaches and Tools in Education and Training, Dordrencht: Kluwer Academic Publisher.

Depdiknas. 2003. Standar Kompetensi Mata Pelajaran TIK untuk SD/MI. Jakarta: Depdiknas

http://aan.wordpress.com/2009/penelitianpenge mbangan, 27 Juli 2010

Iif Khoiru Ahmadi dkk. 2011. Pembelajaran Akselerasi. Jakarta: Prestasi Pustaka Publisher

2010. Strategi Pembelajaran SBI. Jakarta: Prestasi Pustaka Publisher.

Rosyid. 2010. Pengertian, Fungsi, Tujuan, Penulisan Modul. http://rosyidmarh.word press.com. 15 Agustus 2010.

Santyasa, 2009. Teori Pengembangan Modul. http://nurma.staff.uns.ac.id.27 Oktober 2010

Suryosubroto.1993. Sistem Pengajaran dengan Modul. Jakarta:Bina Aksara

Vembriarto. 1981. Pengajaran Modul. Yogyakarta: Yayasan Pendidikan Paramita. 